\title{
High risk pregnancies and factors associated with neonatal death*
}

\author{
Gestação de alto risco e fatores associados ao óbito neonatal \\ Gestación de alto riesgo y factores asociados con la defunción neonatal
}

\author{
Marcela de Oliveira Demitto ${ }^{1}$, Angela Andréia França Gravena ${ }^{1}$, Cátia Millene Dell'Agnolo ${ }^{1}$, Marcos Benatti Antunes ${ }^{1}$, \\ Sandra Marisa Pelloso ${ }^{1}$
}

How to cite this article:

Demitto MO, Gravena AAF, Dell'Agnolo CM, Antunes MB, Pelloso SM. High risk pregnancies and factors associated with neonatal death. Rev Esc Enferm USP. 2017;51:e03208. DOI: http://dx.doi.org/10.1590/S1980-220X2016014703208

*Extracted from the thesis "Gestantes de risco atendidas na Rede Mãe Paranaense: prematuridade e óbito neonatal", Programa de Pós-Graduação em Enfermagem, Universidade Estadual de Maringá, 2015.

${ }^{1}$ Universidade Estadual de Maringá, Maringá, PR, Brazil.
Corresponding author:

Marcela de Oliveira Demitto

Universidade Estadual de Maringá

Av. Colombo, 5790

CEP 87020-900 - Maringá, Paraná, Brazil

mar_demitto@hotmail.com

\begin{abstract}
Objective: To identify the factors associated with intra-hospital neonatal mortality based on the individual characteristics of at-risk pregnant mothers, delivery and newborns. Method: This was a cross-sectional epidemiological study of live newborns delivered by women attended at the high-risk outpatient unit of a philanthropic hospital in Maringá, Paraná, Brazil between September 2012 and September 2013. Results: Six hundred and eighty-eight women participated in the study. The neonatal mortality coefficient found was $17.7 / 1,000$ live births, most in the early neonatal phase. Premature labor, fetal malformation and multiple gestations were associated with neonatal death. Premature, very low birth weight newborns and those with an Apgar score of less than seven, five minutes after birth were at high risk of death. Conclusion: Identifying risk factors can help plan actions to consolidate the perinatal network. Specific programs should be incentivized in other countries, in the search for significant perinatal results such as reducing neonatal mortality.
\end{abstract}

\section{DESCRIPTORS}

Pregnancy, High-Risk; Infant mortality; Neonatal Nursing; Maternal-Child Nursing; Epidemiological Factors; Risk factors. 


\section{INTRODUCTION}

Infant mortality has dropped significantly all over the world. In Brazil, infant mortality dropped from 51 deaths per thousand live births in 1990 to 15 per thousand in $2015^{(1)}$. Even in light of these advances, the infant mortality rate in Brazil is 19.88 deaths per 1,000 live births, ranking the country in $90^{\text {th }}$ place out of 187 nations in the United Nations ranking, behind Cuba (5.25), Chile (6.48), Argentina (12.8), China (15.4) and Mexico (16.5)(2).

If we break down infant mortality by age, worldwide, neonatal ( 0 to 27 days) deaths account for $44 \%$ of all deaths among children under the age of five ${ }^{(3)}$. In Brazil this component is even larger, and can be as high as $70 \%$ in all regions ${ }^{(2)}$, with 11.2 deaths per thousand live births between 2011 and 2012(4).

In the state of Paraná, neonatal deaths dropped from 2,426 in 1996 to 1,279 in 2014 (94.8\% less). However, in spite of all the progress made, $71.8 \%$ of infant deaths in 2014 were in the neonatal period ${ }^{(5)}$. According to the Report on Levels and Trends in Infant Mortality (Relatório de Niveis $e$ Tendência em Mortalidade Infantil), the main goal is to reduce mortality in the neonatal period, which is where most infant deaths occur ${ }^{(1)}$.

To reduce maternal and infant mortality, and the high percentage of avoidable deaths, in 2012 a public policy for prenatal care and for the care of newborns at risk was created in Paraná. It focuses on early detection of pregnant women at risk, their prenatal care, risk stratification of mothers and infants, specialized ambulatory care for pregnant women and infants (under the age of one) at risk, and ensured delivery via a system that is linked to the hospital ${ }^{(6)}$.

Numerous studies have attempted to analyze the causes of neonatal deaths. Studies show a strong link between neonatal deaths and maternal and infant life conditions and health, economic situation, and access to healthcare, and to biological conditions such as gestational age, weight at birth and Apgar index ${ }^{(7)}$. We also call attention to the risk in the current and previous pregnancy (prior stillbirth, premature or low birth weight infants), the movement of the pregnant woman to delivery and women giving birth to low-weight babies $(<1,500$ grams) in hospitals not equipped with a Neonatal Intensive Care Unit (NICU) $)^{(4)}$. Studies show that among newborns in NICU, Cesarean birth, failure to use steroids, pre-eclampsia, oligohydramnios, $<2,500$ grams at birth, Apgar $<7$ in the fifth minute of life, endotracheal intubation and failure to use a surfactant are also associated with neonatal death ${ }^{(8)}$.

Death in this period reflects socioeconomic and reproductive conditions, and is also related to the quality of pre-natal care and care during delivery, revealing gaps in the healthcare network ${ }^{(9-10)}$. Given the significance of neonatal mortality as an indicator of maternal/infant health, this study aimed to identify the facts associated with intra-hospital neonatal mortality based on the individual characteristics of at-risk mothers, the delivery and the newborn.

\section{METHOD}

\section{StUdY DESIGN AND POPULATION}

This was a cross-sectional epidemiological study on newborns delivered by 688 women followed by the highrisk outpatient unit of a philanthropic hospital in Maringá, Paraná, Brazil, between September 2012 and September 2013. This period corresponds to the first year of the care program for high-risk pregnant women and newborns ${ }^{(7)}$. Stillbirths were not included in this study.

\section{DATA GATHERING AND STUDY VARIABLES}

The data were gathered by researchers between May and August 2014 and were taken from the pregnant woman's hospital records, which include a tool for evaluating gestation risk based on the following indicators: pre-existing clinical conditions (arterial hypertension, heart diseases, lung diseases, renal diseases, endocrine diseases, blood diseases, infectious illnesses and drug dependency), and obstetrical history (fetal and neonatal deaths, $<2,500$ grams at birth, more than three Cesareans, placental accreta, bleeding in the second semester, pre-eclampsia, cervical cerclage, premature amniorrhexis, premature labor, premature delivery, repeated miscarriages), and clinical incidents (urinary tract infection, rubella, toxoplasmosis, gestational-specific hypertension, intrauterine growth limitations, premature labor, placenta previa, premature amniorrhexis, $\mathrm{RhD}$ alloimmunization, fetal malformation, concept macrosomia, multiple gestation $)^{(5)}$. We also used birth records and newborn death certificates to complement the information in the file and check cause of death.

The dependent variable was death during the neonatal period. The independent variables were split into three groups: I - Maternal social, economic and demographic characteristics: race/skin color (white, brown or black), marital status (married, divorced, single or widowed), years of schooling (fewer than 8 years, 8 or more years), occupation (paid or non-paid), city of residence (Maringá or other cities and towns), religion (Catholic, other), age (19 or under, 20-34, 35 or older); II - Assessment of gestational risk: preexisting clinical conditions, obstetrical history and clinical incidents in the current gestation; III - Overall delivery and newborn characteristics: type of gestation, type of delivery, parity, gestational age, newborn gender, weight at birth, Apgar index at one and five minutes. Cause of death was taken from the death certificate.

Missing (unknown) data is not included in the tables.

\section{DATA ANALYSIS}

The initial analysis showed a relationship between neonatal death and variables in all three groups. We used an Odds Ratio (OR) analysis of the gross data to analyze the association between risk factors and outcome using Epi Info 3.5.1, with a level of significance of 5\%. After this, to assess the possible confusion variables in the bivariate analysis, we used logistics regression to select the variables with a level of significance of less than $0.20(p \leq 0.20)$. We used Statistica 7.1 with significance level of of $5 \%$ and $95 \%$ Confidence Interval. 


\section{ETHICAL ASPECTS}

This study complies with National Health Board Standards and Guidelines Governing Research Involving Human Beings (CNS (Conselho Nacional de Saúde) Resolution 466/2012), and was approved with Opinion n. 681317/2014.

\section{RESULTS}

Six hundred and eighty-eight women and 732 live newborns were involved in the study, all coming from the highrisk outpatient unit. Among the births was one case of triplets and 42 women had twins. All medical files were reviewed, although there were gaps in the data. The neonatal mortality coefficient was 17.7 per thousand live births (1.8\%), with a total of 13 neonatal deaths, $76.9 \%$ in the early neonatal period (0-6 days), and $23.1 \%$ in the late neonatal period (7-27 days).

Regarding the cause of the neonatal deaths, premature birth topped the list and accounted for 92.3\%. This was followed by infection (46.1\%), neonatal anoxia (46.1\%), maternal factors (23.0\%) and congenital malformations (15.3\%). Other causes were present in smaller numbers, such as lung and gastric bleeding, cardiorespiratory arrest, acute renal failure and persistently patent arterial duct.

While we found more neonatal deaths among the children of white women who were married, gainfully employed, catholic, aged 20 to 34 with more years of schooling, we found no statistical association between these variables and neonatal death (Table 1).

Table 1 - Social, economic and demographic characteristics of pregnant women followed by the high-risk outpatient clinic, according to neonatal death - Group I - Maringá, Paraná, Brazil, 2014.

\begin{tabular}{|c|c|c|c|c|c|}
\hline \multirow{3}{*}{ Variables } & \multicolumn{5}{|c|}{ Neonatal Death } \\
\hline & \multicolumn{2}{|c|}{ Yes* } & \multicolumn{2}{|c|}{ No* } & \multirow{2}{*}{$p$} \\
\hline & $\mathbf{n}$ & $\%$ & $\mathbf{n}$ & $\%$ & \\
\hline \multicolumn{6}{|l|}{ Age } \\
\hline 19 or younger & 2 & 2.8 & 69 & 97.2 & \multirow{3}{*}{0.75} \\
\hline $20-34$ & 9 & 1.9 & 460 & 98.1 & \\
\hline$\geq 35$ & 2 & 1.4 & 146 & 98.6 & \\
\hline \multicolumn{6}{|l|}{ Years of schooling } \\
\hline 8 or less & 2 & 1.3 & 156 & 98.7 & \multirow{2}{*}{0.39} \\
\hline$\geq 8$ & 11 & 2.1 & 519 & 97.9 & \\
\hline \multicolumn{6}{|l|}{ Race/Color } \\
\hline White (Caucasian) & 9 & 2.1 & 415 & 97.9 & \multirow{3}{*}{0.67} \\
\hline Brown & 4 & 1.7 & 228 & 98.3 & \\
\hline Black & - & - & 32 & 100.0 & \\
\hline \multicolumn{6}{|l|}{ City of Residence } \\
\hline Maringá & 8 & 2.6 & 301 & 97.4 & \multirow{2}{*}{0.17} \\
\hline Other locations & 5 & 1.3 & 374 & 98.7 & \\
\hline \multicolumn{6}{|l|}{ Marital status } \\
\hline Married & 10 & 2.5 & 394 & 97.5 & \multirow{4}{*}{0.59} \\
\hline Divorced & 0 & 0 & 11 & 100 & \\
\hline Single & 3 & 1.1 & 263 & 98.9 & \\
\hline Windowed & - & - & 5 & 100.0 & \\
\hline \multicolumn{6}{|l|}{ Religion } \\
\hline Catholic & 9 & 2.1 & 410 & 97.9 & \multirow{2}{*}{0.37} \\
\hline Other & 4 & 1.5 & 265 & 98.5 & \\
\hline \multicolumn{6}{|l|}{ Occupation } \\
\hline Paid & 7 & 1.7 & 395 & 98.3 & \multirow{2}{*}{0.72} \\
\hline Unpaid & 6 & 2.1 & 278 & 97.9 & \\
\hline
\end{tabular}

*Unknown data was excluded.

Among the overall delivery characteristics (type of gestation, type of delivery, parity, gestational age) and of the newborn (gender, weight at birth, Apgar at minute one and five), in both the bivariate analysis as well as logistics regression neonatal death was associated with premature birth, very low birth weight and Apgar lower than seven in the fifth minute of life (Table 2).

In terms of gestational risk, we found no relationship between pre-existing conditions and neonatal death. In terms of clinical incidents during the current gestation, 
after a logistic regression analysis, women who went into premature labor and birth, fetal malformations and multiple gestations presented high risk for an outcome of neonatal death (Table 3).

Table 2 - Overall characteristics of the delivery and newborn of women followed by the high-risk outpatient unit, according to neonatal death - Group III - Maringá, Paraná, Brazil, 2014.

\begin{tabular}{|c|c|c|c|c|c|c|}
\hline \multirow[b]{2}{*}{ Variables } & \multicolumn{6}{|c|}{ Neonatal Deaths } \\
\hline & $\begin{array}{l}\text { Yes* } \\
\text { n (\%) }\end{array}$ & $\begin{array}{l}\text { No* } \\
(\text { (n\%) }\end{array}$ & Gross OR (Cl 95\%) & $p$ & OR Adjusted (Cl 95\%) & $p$ \\
\hline \multicolumn{7}{|c|}{ Gestational Age (weeks) } \\
\hline$<28$ & $5(55.6)$ & $4(44.4)$ & 69.37 (54.00-203.39) & $<0.001$ & $682.47(64.31-7241.65)$ & $<0.001$ \\
\hline $28-31$ & $4(28.6)$ & $10(71.4)$ & $22.00(2.05-740.98)$ & $<0.001$ & $260.61(25.24-2690.63)$ & $<0.001$ \\
\hline $32-36$ & $2(1.8)$ & $107(98.2)$ & $10.37(0.73-29.41)$ & 0.07 & $11.30(1.01-127.07)$ & 0.04 \\
\hline$\geq 37$ & $1(0.2)$ & $555(99.8)$ & 1.0 & & & \\
\hline \multicolumn{7}{|l|}{ Parity } \\
\hline Primiparous & $4(2.1)$ & $190(97.9)$ & $1.26(0.32-4.66)$ & 0.74 & & \\
\hline Multiparous & $8(1.6)$ & $478(98.4)$ & 1.0 & & & \\
\hline \multicolumn{7}{|c|}{ Type of Delivery } \\
\hline Cesarean & $9(1.8)$ & $500(98.2)$ & $0.78(0.22-3.06)$ & 0.74 & & \\
\hline Normal & $4(2.2)$ & $174(97.8)$ & 1.0 & & & \\
\hline \multicolumn{7}{|c|}{ Type of Gestation } \\
\hline Single & $10(1.6)$ & $632(98.4)$ & 1.0 & & & \\
\hline Multiple & $2(4.7)$ & $41(95.3)$ & $3.08(0.01-15.73)$ & 0.17 & $0.49(0.04-5.28)$ & 0.56 \\
\hline \multicolumn{7}{|l|}{ Gender } \\
\hline Female & $5(1.4)$ & 344 (98.6) & $0.77(0.21-2.74)$ & 0.66 & & \\
\hline Male & $7(1.8)$ & $373(98.2)$ & 1.0 & & & \\
\hline \multicolumn{7}{|c|}{ 5-minute Apgar } \\
\hline$<7$ & $7(35.0)$ & $13(65.0)$ & $75.82(18.37-326.86)$ & $<0.001$ & $36.36(5.35-247.13)$ & $<0.001$ \\
\hline$\geq 7$ & $5(0.7)$ & $704(99.3)$ & 1.0 & & & \\
\hline \multicolumn{7}{|c|}{ Weight at birth (grams) } \\
\hline$<1500$ & $9(36.0)$ & $16(64.0)$ & $34.13(8.90-475.92)$ & $<0.001$ & $217.73(22.18-2137.08)$ & $<0.001$ \\
\hline $1500-2499$ & $2(1.9)$ & $105(98.1)$ & $11.31(0.80-317.90)$ & 0.06 & $7.46(0.61-90.73)$ & 0.11 \\
\hline$\geq 2500$ & $1(0.2)$ & $594(99.8)$ & 1.0 & & & \\
\hline
\end{tabular}

*Unknown data was excluded.

Table 3 - Stratification of gestational risk, preexisting clinical conditions, obstetrical history and clinical incidents during the current gestation of women seen at the high-risk outpatient unit, according to neonatal death - Group II - Maringá, Paraná, Brazil, 2014.

\begin{tabular}{|c|c|c|c|c|c|c|}
\hline \multirow[b]{2}{*}{ Risk stratification } & \multicolumn{6}{|c|}{ Neonatal Death } \\
\hline & $\begin{array}{c}\text { Yes* } \\
\text { n (\%) }\end{array}$ & $\begin{array}{l}\text { No* } \\
(\mathrm{n} \%)\end{array}$ & Gross OR (Cl 95\%) & $p$ & OR Adjusted (Cl 95\%) & $p$ \\
\hline \multicolumn{7}{|l|}{ Obstetrical history } \\
\hline Fetal and neonatal death & $4(7.4)$ & $50(92.6)$ & $5.56(1.38-20.69)$ & 0.001 & $3.60(0.93-13.89)$ & 0.06 \\
\hline Low birth weight & $3(6,7)$ & $42(93.3)$ & $4.52(0.95-18.77)$ & 0.04 & $1.74(0.27-11.11)$ & 0.55 \\
\hline Premature labor & $3(6.3)$ & $45(93.8)$ & $6.22(1.54-23.29)$ & 0.01 & $3.58(0.65-19.53)$ & 0.13 \\
\hline Premature labor & $3(6.0)$ & $47(94.0)$ & $4.01(0.84-16.64)$ & 0.06 & $0.85(0.11-6.31)$ & 0.87 \\
\hline \multicolumn{7}{|c|}{ Clinical incidents during the current gestation } \\
\hline Premature labor & $3(10.7)$ & $25(89.3)$ & $7.80(1.59-33.58)$ & 0.01 & $11.43(2.70-48.27)$ & $<0.001$ \\
\hline Fetal malformation & $2(6.9)$ & $27(93.1)$ & $4.36(0.01-22.50)$ & 0.10 & $7.92(1.50-41.67)$ & 0.01 \\
\hline Multiple gestations & $3(6.0)$ & $47(94.0)$ & $4.01(0.84-16.54)$ & 0.06 & $6.01(1.45-24.87)$ & 0.01 \\
\hline
\end{tabular}

*Unknown data was excluded. 


\section{DISCUSSION}

This is the first Brazilian study aimed at analyzing the factors associated with mortality during the neonatal period, based on a public healthcare policy focused on high-risk pregnancies, identifying health conditions of the mother and newborn that increase the risk of death during the neonatal period.

The neonatal mortality coefficient in this study $(17.7$ deaths/1,000 live births) is below the 2012 world average $(21 / 1,000 \text { live births })^{(3)}$, but far above that found in other parts of Brazil, such as the south, southeast, middle-west and northeast, at 6.1, 8.0, 8.4 and 14.5 deaths per 1,000 live births respectively ${ }^{(4)}$. One should use caution when comparing these numbers however, as this study was based on women with high-risk pregnancies.

The higher percent of deaths in the early neonatal phase corroborates data in the literature showing that this period is the main component of infant death worldwide, with many $(25 \%)$ of the deaths happening in the first 24 hours $^{(11)}$.

In this study, an Apgar below seven was statistically associated with neonatal death. A recent study of 1,029,207 live births in Salvador showed that an Apgar of less than seven in the fifth minute of life was associated with a higher risk of neonatal death. This association was even stronger at Apgars between 0 and 3 , showing the importance of this assessment in contemporary practice ${ }^{(12)}$.

An Apgar of less than seven in the fifth minute of life shows a need for immediate care to minimize the consequences of poor brain oxygenation ${ }^{(13)}$. A high risk of neonatal death in cases of asphyxia/hypoxia may be related to poorly trained professionals and the absence of suitable technological resources. This is thus a sensitive indicator of the quality of the care provided during labor and delivery ${ }^{(14)}$.

This study showed that only very low birth weight newborns $(<1,500$ grams) were at risk of death during the neonatal period $(\mathrm{OR}=217.73)$, which may be explained by the fact that these infants required long periods in the NICU to gain weight, exposing them to infections and other complications ${ }^{(15)}$.

Low birth weight is an important characteristic of the newborn, and is the main isolated predictor of neonatal death, with evidence of higher risk of death as birthweight goes down ${ }^{(4,16)}$.

The existence of clinical incidents during gestation may predict adverse perinatal results that may have as an outcome neonatal death ${ }^{(17)}$. In this study, fetal malformation, multiple gestations and premature labor were shown to be important risk factors for neonatal death, corroborating the Nascer no Brasil (Birth in Brazil) Survey ${ }^{(4)}$.

A study of neonatal infant mortality among the offspring of high-risk pregnant women in Brazil shows that, of the newborn who died, $20.8 \%$ had congenital malformations like hydrocephaly, emphalocelle and renal malformation ${ }^{(18)}$. In a cohort study performed in Brazil, congenital malformation increased the risk of neonatal death $15.5-$ fold $^{(18)}$, suggesting the need to invest in early diagnosis, clinical and surgical treatment, and primary prevention to improve the evolution of these cases ${ }^{(19)}$.
This survey included 42 gemellar and one triplet pregnancy. Regarding the type of gestation, it is known that newborns of multiple pregnancies are at higher risk of being premature and have low birth weight. Because of this, gemellarity is also considered a maternal factor associated with neonatal death ${ }^{(16)}$.

Newborns of women with premature labor are 11 times more likely to die in the neonatal period. It is known that in these cases ante-natal corticosteroids and surfactants after birth are care practices that can minimize respiratory failure resulting from pulmonary immaturity of the newborn, with a positive impact on neonatal mortality ${ }^{(20)}$.

Of the 13 neonatal deaths in this study, 12 were premature infants. A survey of premature and very low birth weight newborns found that those receiving a corticosteroid in the antenatal period were 3 times less likely to die in the neonatal period, and required 2.4 times less resuscitation, compared to those not receiving a corticosteroid ${ }^{(21)}$.

Worldwide, $34 \%$ of neonatal deaths are due to the complications of premature birth ${ }^{(3)}$. In this survey, premature birth was present in almost all cases of neonatal death, followed by health problems that are likely related to this, such as infection and anoxia, which alerts to the need for measures focused on prevention, starting with early identification of the factors of pre-natal risk.

The variables indicating increased severity of newborns are statistically associated with neonatal death. These include premature birth, very low birth weight and Apgar less than seven in the fifth minute of life, factors also found in other studies ${ }^{(15,22-23)}$.

Premature birth and neonatal mortality are inversely related. In other words, the smaller the gestational age of the newborn, the higher the risk of death, leading to a global concern with premature birth rates. In 2010, more than one in ten live births were premature, or about 15 million (11.1\%), over a million of whom died because they were premature $^{(24)}$. It is the main cause of neonatal morbidity and mortality ${ }^{(25-26)}$, and a major challenge for public health.

In a recent study, adolescents, tobacco users, those with a diagnosis of diabetes or hypertension, multiple pregnancies, a history of gestational diabetes, fetal anomaly and miscarriages were associated with a higher incidence of prematurity $^{(27)}$. In Porto Alegre, low birth weight (< 2,500 grams), inadequate prenatal care, 5-minute Apgar between 0 and 3, Cesarean delivery, multiple pregnancies, mothers below the age of 19 or above 34 , and inadequate maternal education were also associated with prematurity ${ }^{(28)}$. Because it is one of the main causes of neonatal death, investigating prematurity and the associated factors may reveal indirect risk factors that must be taken into consideration for prevention. Our research shows that many of the risk factors for prematurity, such as multiple gestations, fetal anomalies and low birth weight were associated with fetal death.

This shows that investment is required in measures to prevent avoidable prematurity, such as focusing on pre-natal care, in particular high-risk pregnancies, and prevention of iatrogenic prematurity, related with unnecessary pregnancy interruption, such as inadequately indicated Cesareans ${ }^{(29)}$. 
In light of the characteristics of gestational risk of the women in this study, and the results found, we stress the importance of quality service that can handle highly complex deliveries and newborns. Some studies have shown that infants transferred to other facilities due to the absence of the conditions required to safely care for the mothers and newborns in serious condition have a high probability of death during the neonatal period ${ }^{(4)}$. Furthermore, infants born of women who do not get suitable pre-natal care, who are born at home and have no post-natal care are also at higher risk of death before they are 28 days old ${ }^{(30)}$.

In this regard, we highlight one of the pillars of care for high-risk pregnant women in the region, which is ensure delivery in hospitals with $\mathrm{NICU}^{(6)}$, which guarantees better results in terms of the risk of neonatal death ${ }^{(4)}$.

One of the limitations of this study was the use of file data and birth and death records, thus depending on the quality with which they were filled out by professionals, as we often found missing (unknown) data not included in the tables. We do not know how gestational age was estimated, if ultrasound or the date of the last menstrual period, something that could affect the classification of premature birth.

\section{CONCLUSION}

This study found risk factors for neonatal death among women with high-risk pregnancies, early labor, fetal malformation and multiple current gestation. In addition to prematurity, very low birth weight and an Apgar of less than seven in the fifth minute of life.

Identifying risk factors can help plan actions to consolidate the perinatal network, restructuring and qualifying pre-natal care for high-risk pregnancies, delivery and care of the newborn.

Specific programs that focus on high-risk pregnancies, ensuring delivery in a hospital capable of handling highly complex cases, must be encouraged in other developing countries, and even in other regions of Brazil, in the search for significant perinatal results, such as lower neonatal mortality.

\section{RESUMO}

Objetivo: Identificar os fatores associados à mortalidade neonatal intra-hospitalar com base nas características individuais de gestantes de risco, do parto e do recém-nascido. Método: Estudo epidemiológico do tipo transversal, realizado com crianças nascidas vivas de partos hospitalares de mulheres acompanhadas pelo ambulatório de alto risco de um hospital filantrópico de Maringá, Paraná, Brasil, no período de setembro de 2012 a setembro de 2013. Resultados: Fizeram parte da pesquisa 688 mulheres. O coeficiente de mortalidade neonatal foi de 17,7 óbitos/1.000 nascidos vivos, sendo sua maioria no período neonatal precoce. Trabalho de parto prematuro, malformação fetal e gestação múltipla foram as intercorrências associadas ao óbito neonatal. Recém-nascidos prematuros, com muito baixo peso ao nascer e Índice de Apgar menor que sete no quinto minuto de vida apresentaram risco elevado de morte. Conclusão: A identificação de fatores de risco pode auxiliar no planejamento de ações para consolidação da rede perinatal. Programas específicos devem ser incentivados em outros países, na busca de resultados perinatais expressivos, como a redução da mortalidade neonatal.

\section{DESCRITORES}

Gravidez de Alto Risco; Mortalidade Infantil; Enfermagem Neonatal; Enfermagem Materno-Infantil; Fatores Epidemiológicos; Fatores de Risco.

\section{RESUMEN}

Objetivo: Identificar los factores asociados con la mortalidad neonatal intrahospitalaria con base en las características individuales de gestantes de riesgo, del parto y del recién nacido. Método: Estudio epidemiológico del tipo transversal, realizado con niños nacidos vivos de partos hospitalarios de mujeres seguidas en el ambulatorio de alto riesgo de un hospital filantrópico de Maringá, Paraná, Brasil, en el período de septiembre de 2012 a septiembre de 2013. Resultados: Hicieron parte de la investigación 688 mujeres. El coeficiente de mortalidad neonatal fue de 7,7 defunciones/1.000 nacidos vivos, siendo su mayoría en el período neonatal precoz. Trabajo de parto prematuro, malformación fetal y gestación múltiple fueron los sucesos asociados con la defunción neonatal. Recién nacidos prematuros, con muy bajo peso al nacer e Indice de Apgar menor que siete el quinto minuto de vida presentaron riesgo elevado de muerte. Conclusión: La identificación de factores de riesgo puede auxiliar la planificación de acciones para consolidación de la red perinatal. Se deben incentivar programas específicos en otros países, en la búsqueda por resultados perinatales considerables, como la reducción de la mortalidad neonatal.

\section{DESCRIPTORES}

Embarazo de Alto Riesgo; Mortalidad Infantil; Enfermería Neonatal; Enfermería Materno-Infantil; Factores Epidemiológicos; Factores de Riesgo.

\section{REFERENCES}

1. United Nations Children's Fund. Levels and trends in child mortality. Report 2015. Estimates Developed by the UN Inter-agency Group for Child Mortality Estimation [Internet]. Geneva: UNICEF; 2015 [cited 2016 Aug 09]. Available from: http://www.unicef.org/publications/ files/Child_Mortality_Report_2015_Web_8_Sept_15.pdf

2. Brasil. Ministério da Saúde; Secretaria de Ciência, Tecnologia e Insumos Estratégicos, Departamento de Ciência e Tecnologia. Síntese de evidências para Políticas de Saúde: mortalidade perinatal [Internet]. Brasília; 2012 [citado 2014 ago. 25]. Disponível em: http://bvsms. saude.gov.br/bvs/publicacoes/sintese_evidencias_mortalidade_perinatal.pdf

3. United Nations Children's Fund. Committing to child survival: a promise renewed. Progress report; 2013 [Internet]. Geneva: UNICEF; 2013 [cited 2014 Aug 25]. Available from: http://www.un.org/youthenvoy/2013/09/unicef-the-united-nations-childrens-fund/ 
4. Lansky S, Friche AAL, Silda AAM, Campos D, Bittencourt SDA, Carvalho ML, et al. Pesquisa Nascer no Brasil: perfil da mortalidade neonatal e avaliação da assistência à gestante e ao recém-nascido. Cad Saúde Pública. 2014;30 Supl:S192-207.

5. Brasil. Ministério da Saúde. DATASUS. Informações de Saúde. Óbitos Infantis. Paraná. [Internet]. Brasília; 2016 [citado 2016 ago. 09]. Disponível em: http://tabnet.datasus.gov.br/cgi/tabcgi.exe?sim/cnv/inf10pr.def

6. Paraná. Secretaria de Estado da Saúde. Superintendência de Atenção à Saúde. Linha Guia Rede Mãe Paranaense [Internet]. Curitiba; 2013 [citado 2014 ago. 25]. Disponível em: http://www.saude.pr.gov.br/arquivos/File/MaeParanaense_2014_LinhaGuia_Ed03_148x210mm_1.pdf

7. Kassar SB, Melo AMC, Coutinho SB, Lima MC, Lira PIC. Determinants of neonatal death with emphasis on health care during pregnancy, childbirth and reproductive history. J Pediatr. 2013;89(3):269-77.

8. Silva CF, Leite AJM, Almeida NMGS, Leon ACMP, Olofin I. Fatores associados ao óbito neonatal de recém-nascidos de alto risco: estudo multicêntrico em Unidades Neonatais de Alto Risco no Nordeste brasileiro. Cad Saúde Pública. 2014:30(2):355-68.

9. Nascimento RM, Leite AJ, Almeida NM, Almeida PC, Silva CF. Determinantes da mortalidade neonatal: estudo caso-controle em Fortaleza, Ceará, Brasil. Cad Saúde Pública. 2012;28(3):559-72.

10. Rajaratnam JK, Marcus JR, Flaxman AD, Wang H, Levin-Rector A, Dwyer L, et al. Neonatal, postneonatal, childhood, and under-5 mortality for 187 countries, 1970-2010: a systematic analysis of progress towards Millennium Development Goal 4. Lancet. 2010;375(9730):1988-2008.

11. França E, Lansky S. Mortalidade infantil neonatal no Brasil: situação, tendências e perspectivas. In: Rede Interagencial de Informações para Saúde, organizador. Demografia e saúde: contribuição para análise de situação e tendências. Brasília: OPAS; 2009. p. 83-112.

12. Iliodromiti S, Mackay DF, Smith GC, Pell JP, Nelson SM. Apgar score and the risk of cause-specific infant mortality: a population-based cohort study. Lancet. 2014;14(9956):1749-55.

13. Brasil. Ministério da Saúde; Secretaria de Atenção à Saúde, Departamento de Ações Programáticas e Estratégicas. Atenção à saúde do recém-nascido: guia prático para os profissionais de saúde [Internet]. Brasília; 2011 [citado 2014 ago. 25]. Disponível em: http://www. redeblh.fiocruz.br/media/arn_v3.pdf

14. Lozano R, Wang H, Foreman KJ, Rajaratnam JK, Naghavi M, Marcus JR, et al. Progress towards millennium development goals 4 and 5 on maternal and child mortality: an updated systematic analysis. Lancet. 2011;378(9797):1139-65.

15. Ghojazadeh M, Velayati A, Mallah F, Azami-Aghdash S, Mirnia K, Piri R, Naghavi-Behzad M. Contributing death factors in very low-birthweight infants by path method analysis. Niger Med J. 2014;55(5):389-93.

16. Lima EFA, Sousa AI, Griep RH, Primo CC. Fatores de risco para mortalidade neonatal no município de Serra, Espírito Santo. Rev Bras Enferm. 2012;65(4):578-85.

17. Kumar GA, Dandona R, Chaman P, Singh P, Dandona L. A population-based study of neonatal mortality and maternal care utilization in the Indian state of Bihar. BMC Pregnancy Childbirth. 2014;14:357.

18. Silva RCAF, Monteiro PS. Perinatal mortality in high-risk pregnant women in a tertiary hospital. J Health Biol Sci. 2014;2(1):22-7.

19. Gomes MRR, Costa JSD. Mortalidade infantil e as malformações congênitas no Município de Pelotas, Estado do Rio Grande do Sul, Brasil: estudo ecológico no período 1996-2008. Epidemiol Serv Saude. 2012;21(1):119-28.

20. Almeida MFB, Guinsburg R, Martinez FE, Procianoy RS, Leone CR, Marba STM, et al. Fatores perinatais associados ao óbito precoce em prematuros nascidos nos centros da Rede Brasileira de Pesquisas Neonatais. Arch Pediatr Urug. 2010;81(2):112-20.

21. Drummond S, Souza TS, Lima FG, Vieira AA. Correlação entre o uso de corticoterapia antenatal, a reanimação e a mortalidade de recémnascidos prematuros de muito baixo peso. Rev Bras Ginecol Obstet. 2014;36(5):211-5.

22. Oliveira ARRO, Llerena Junior JC, Cosata MFS. Perfil dos óbitos de recém-nascidos na sala de parto de uma maternidade do Rio de Janeiro, 2010-2012. Epidemiol Serv Saúde. 2013;22(3):501-8.

23. Borges TS, Vayego SA. Fatores de risco para mortalidade neonatal em um município na região Sul. Ciênc Saúde. $2015 ; 8(1): 7-14$.

24. Blencowe $\mathrm{H}$, Cousens S, Oestergaard MZ, Chou D, Moller AB, Narwal R, et al. National, regional, and worldwide estimates of preterm birth rates in the year 2010 with time trends since 1990 for selected countries: a systematic analysis and implications. Lancet. $2012 ; 12(9832): 2162-72$.

25. Lopes SAVA, Mendes CMC. Prematuridade e assistência pré-natal em Salvador. Rev Ciênc Méd Biol. 2013;12(4):460-4.

26. Liu L, Johnson H, Cousens S, Perin J, Scott S, Lawn JE, et al. Global, regional and national causes of child mortality: an updated systematic analysis. Lancet. 2012;379(9832):2151-61.

27. Tuon RA, Ambrosano GMB, Vidal e Silva SMC, Pereira AC. Impacto do monitoramento telefônico de gestantes na prevalência da prematuridade e análise dos fatores de risco associados em Piracicaba, São Paulo, Brasil. Cad Saúde Pública. 2016;32(7):e00107014.

28. Oliveira LL, Gonçalves AC, Dias da Costa JS, Bonilha ALL. Maternal and neonatal factors related to prematurity. Rev Esc Enferm USP. 2016;50(3):382-9. DOI: http://dx.doi.org/10.1590/S0080-623420160000400002

29. Victora CG, Aquino EML, Leal MC, Monteiro CA, Barros FC, Szwarcwald CL. Maternal and child health in Brazil: progress and challenges. Lancet. 2011;377(9780):1863-76.

30. Kolola T, Ekubay M, Tesfa E, Morka W. Determinants of Neonatal Mortality in North Shoa Zone, Amhara Regional State, Ethiopia. Plos One. 2016;11(10):e8164472. 